\title{
Placolecis kashmirensis sp. nov. (Lichenized Ascomycota, Catillariaceae) from Azad Jammu \& Kashmir, Pakistan
}

\author{
Robina Kousar, Rizwana Zulfiqar, Abdul Nasir Khalid \\ Fungal Biology and Systematics Lab, Department of Botany, University of the Punjab, \\ Quaid-e-Azam Campus-54590, Lahore, Pakistan \\ E-mail: rizwanamughal6@gmail.com
}

\begin{abstract}
Placolecis kashmirensis sp. nov. is described from Azad Jammu and Kashmir, Pakistan. It is characterized by a yellowish-brown thallus, hyaline, broadly ellipsoid ascospores, a relatively taller hymenium and pear-shaped pycnidia. The generic position is confirmed by a phylogenetic analysis based on nrITS sequences. Description, a phylogenetic tree, and identification key for all the known Placolecis species are provided.
\end{abstract}

Key words: lichen key, lichens, morphology, phylogeny, taxonomy

\section{INTRODUCTION}

The genus Placolecis Trevis. (Catillariaceae) was established in 1857 . The taxon frequently occurs on limestone in open and sunny habitats. It is mainly characterized by crustose to effigurate thallus, a paraplectenchymatous cortex, Catillaria-type asci and simple, hyaline ascospores (Yin et al., 2019). Species from this genus are mainly distributed in the Mediterranean region, and have been infrequently reported from Algeria, Russia (Makryi, 2003), South Korea (Aptroot $\&$ Moon, 2014), and India (Sinha et al., 2015).

The genus was initially established with two species: Placolecis balanina (Fr.) Trevis. and P. plumbea (Lightf.) Trevis. Later on, Hafellner (1984) synonymized one more species Lecidea opaca Dufour into Placolecis, as P. opaca (Dufour) Hafellner, based on the morphological characters and secondary metabolites. In recent studies, $P$. balanina has been merged into $P$. opaca, and $P$. plumbea is treated as synonym of Pectenia plumbea (Lightf.) P. M. Jørg (Yin et al., 2019). In total, four species (Placolecis kunmingensis A.C. Yin \& Li S. Wang, P. loekoesiana (S.Y. Kondr., Farkas, J.J. Woo \& Hur) A.C. Yin, P. opaca (Dufour) Hafellner and P. sublaevis A.C. Yin $\&$ Li S. Wang) are currently accepted in this genus (Yin et al., 2019).

This study adds one more species of Placolecis ( $P$. kashmirensis), to the list of worldwide reported Placolecis species, enhancing its number from four to five. It also makes a new generic record for Pakistan.

\section{MATERIAL AND METHODS}

\section{Collection and preservation}

Specimens were collected during surveys of different sites of District Kotli, Azad Jammu and Kashmir (Pakistan) during the year 2019, focused on an addition to the lichen biota of Pakistan. The specimens were deposited in Department of Botany, University of the Punjab, Lahore (LAH36831).

\section{Morphological and chemical characterization}

Specimens were examined macro- and micromorphologically with a stereomicroscope (Meiji Techno, EMZ-5TR, Japan) and a compound microscope (SWIFT M4000-D) along with System (9MP camera), respectively. Secondary metabolites were detected by thin-layer chromatography in solvent $\mathrm{C}$ as described by Orange et al. (2001). Anatomical characterization and measurement of anatomical features were done by preparing and observing the slides of hand-cut apothecial sections (mounted in water) under microscope. Minimum twenty (20) measurements in water were made for each diagnostic feature.

\section{Molecular characterization and phylogenetic analysis}

For molecular studies, DNA isolation was done and followed by amplification of targeted internal transcribed spacer region (ITS nrDNA), sequencing and phylogeny for accurate identification up to the species level.

Genomic DNA was extracted directly from a portion of thallus with apothecia from each 
specimen using a modified 2\% CTAB method (Gardes \& Bruns, 1993). Extracted DNA was used for PCR amplification of the ITS nrDNA marker using primers pair i.e. ITS1F forward primer (5`CTTGGTCATTTAGAGGAAGTAA 3`) (Gardes \& Bruns, 1993) and ITS4 reverse primer (5' TCCTCCGCTTATTGATATGC 3') (White et al., 1990). The amplified DNA fragments (PCR products) were visualized with the help of $1 \%$ agarose gel using ethidium bromide through Gel documentation system (Sambrook \& Russel, 2001). PCR products were sent for sequencing to Tsingke, China.

The ITS regions of all specimens were amplified and sequenced. Bio-edit sequence alignment editor was used to reassemble forward and reverse sequences (Hall, 2005). Sequences of other Placolecis species from Yin et al. (2019) were used in the phylogenetic analysis (Appendix 1). The multiple sequence alignment was performed using MAFFT v7 with all parameters set to default values (Katoh \& Standley, 2013). The ends of the alignment were trimmed to nearly an equal number of sites for all sequences. All gaps were treated as missing data. Maximum Likelihood analysis was performed with MEGA6 using a GTR model for bootstrapping (Tamura et al., 2013). One thousand rapid bootstrap replicates were run to infer the evolutionary history of each species. Teloschistes flavicans (Sw.) Norman, $T$. exilis (Michx.) Vain., Lecidea tessellata Flörke, and L. atrobrunnea (DC.) Schaer. were selected for rooting purpose of the tree (Yin et al., 2019).

\section{RESULTS}

The length of the final aligned file was $972 \mathrm{nu}-$ cleotides, among which 444 were conserved, 416 variable, 280 parsimony-informative and 77 were singleton variants. Topologies were established based on 24 nrITS sequences including related species of family Catillariaceae and four species for outgroup (Appendix 1). The tree topology obtained from the Maximum Likelihood is used to represent phylogenetic relationships.

The phylogenetic analysis using ITS sequences revealed 20 species, including $P$. kashmirensis new to science (Fig. 1; Fig. 2). The molecular phylogenetic analysis strongly supported the current taxonomic delimitation of the species within the genus of Placolecis, which is in accordance with the taxonomic study based on morphological and chemical characters. The species of the genus Solenospora makes a sister branch relationship with the clade of genus Placolecis, including the Pakistan specimen of $P$. kashmirensis, whereas the species of the genus Austrolecia and Catillaria formed a distant branch relationship with the Placolecis clade.

Placolecis KashmiRensis R. Kousar, R. Zulfiqar \& Khalid sp. nov. (Fig. 2)

Type. Pakistan, Azad Jammu \& Kashmir, Nar, District Kotli; 332 23' 41" N 7349' 43” E, 620 m asl, on calcareous rocks; 19.07.2019; R. Kousar (MAK - 11 - holotype), (LAH36831), GenBank number (MW586931).

Description. Taxon is characterized by yellowishbrown thallus, frequent and plane apothecia, a relatively high hymenium, rather small ascospores and pear-shaped pycnidia. Thallus: crustose to squamulose and lobulate in peripheral zone, definite, well defined, up to $4 \mathrm{~cm}$ across. Colour: yellow to yellowish brown when dry, bright yellow to greenish when wet. Squamules: slightly darker in colour at margins, lobulate, imbricate, confluent, plane, often slightly elevated at margins, smooth. Lobes: $0.5-1 \mathrm{~mm}$ wide at margins, contiguous, shorter and narrower, dichotomously branched to multilobate. The thallus is 170-262 $\mu \mathrm{m}$ thick in section. Upper cortex: outer layer dark brown, 20-28 $\mu \mathrm{m}$ thick, inner layer hyaline, 30-46 $\mu \mathrm{m}$ thick, paraplectenchymatous. Algal layer: continuous, even, $40-57 \mu \mathrm{m}$ thick. Medulla: paraplectenchymatous, reddish brown in the upper portion, prosoplectenchymatous, white in lower portion, overall, 110-133 $\mu \mathrm{m}$ thick, hyphae 3-5 $\mu \mathrm{m}$ in width. Lower cortex: absent. Apothecia: numerous, sessile, lecideine, scattered to crowded. Disc: black, plane, rounded, $0.2-1 \mathrm{~mm}$ in diameter. Margins: distinct, black, thick, continuous, concolourous with the disc, often slightly elevated above the disc. Photobiont: chlorococcoid, cells 14-24 $\mu \mathrm{m}$ in diameter. Exciple: grayish, 50-60 $\mu \mathrm{m}$ thick. Epihymenium: dark brown, 25-40 $\mu \mathrm{m}$ thick, Hymenium: hyaline, 100-130 $\mu \mathrm{m}$ thick, IKI+ blue. Hypothecium: light brown, 45-55 $\mu \mathrm{m}$ thick. Paraphyses: septate, hyaline, capitate, brown pigmented, 3-4 $\mu \mathrm{m}$ wide. Asci: hyaline, clavate, 8-spored, 47-67 × 10$15 \mu \mathrm{m}$. Ascospores: hyaline, broadly ellipsoid, 5-8 $\times 3-5 \mu \mathrm{m}$. Pycnidia: numerous, more or less immersed in thallus, pear shaped, 185-208 $\times$ 120-130 $\mu \mathrm{m}$, ostiole black. Conidia: bacilliform, $4-5 \mu \mathrm{m}$ in length. 


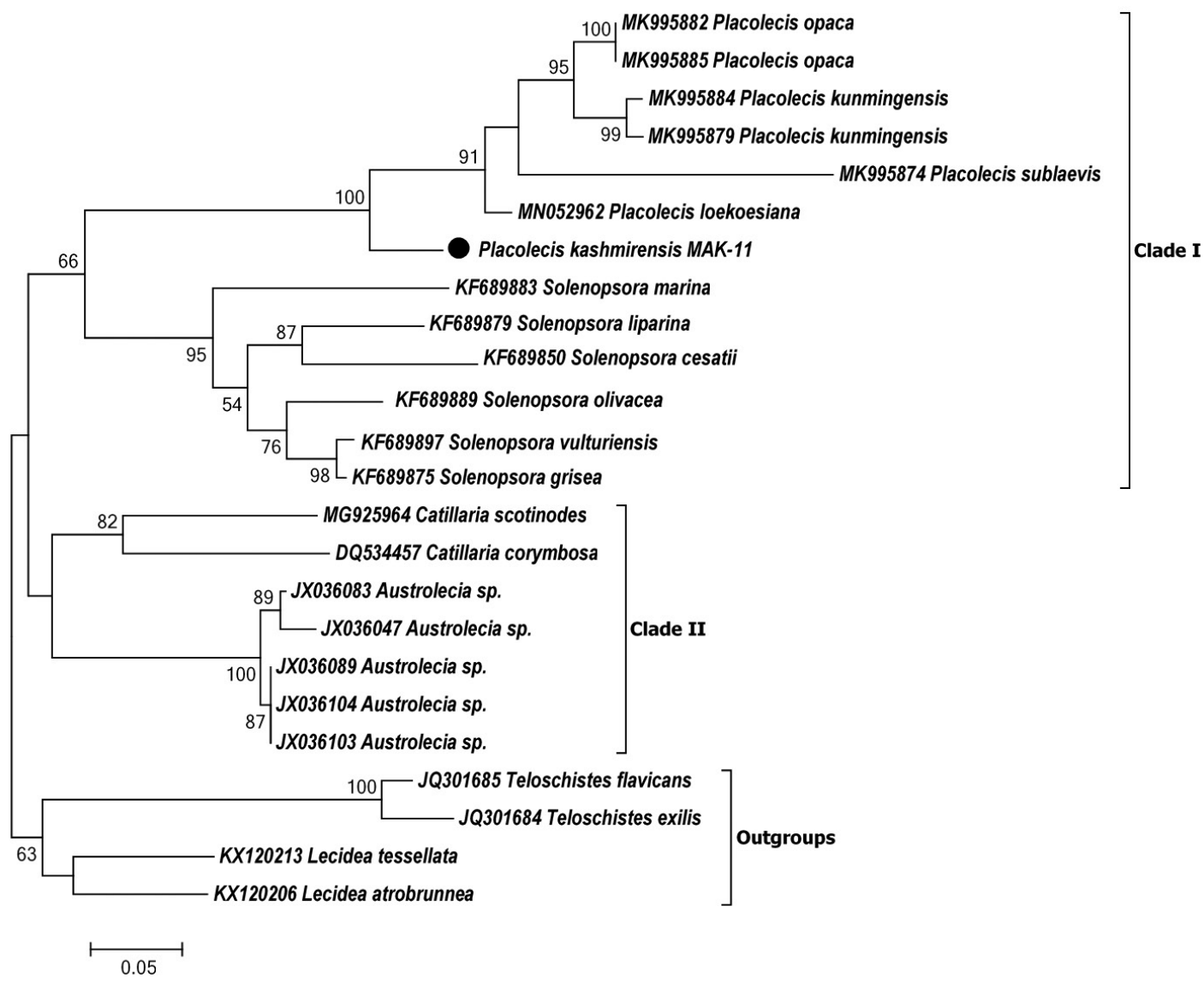

Fig. 1. Phylogenetic relationships of the family Catillariaceae with the genus Placolecis inferred by using Maximum Likelihood method of the ITS sequences. Sequence generated from local collection is marked with $\bullet$. Bootstrap values are shown above branches.

Chemistry. Cortex, $\mathrm{K}+$ (blood red), $\mathrm{C}-, \mathrm{KC}+$ (reddish brown); medulla, $\mathrm{K}+$ (violet), $\mathrm{C}-, \mathrm{KC}+$ (reddish brown). Fragilin and an unknown substance were detected by TLC.

Ecology and distribution. The species is saxicolous, growing on calcareous rocks, collected from sub-tropical chir pine forest, having greater species diversity with the presence of Pinus roxburgii, Quercus incana, Q. glauca, and Ficus spp. The taxon is so far known only from its locus classicus in Nar district Kotli, Azad Jammu \& Kashmir (Pakistan).

Etymology. The epithet kashmirensis (Latin) is based on the type locality Azad Jammu \& Kashmir state, Pakistan, Southern Asia, from where the specimen was collected.
Notes. Despite P. kashmirensis shows molecular affinity to other Placolecis species, they all differ in their morphology and anatomy. In comparison to $P$. sublaevis, $P$. kashmirensis has a bright yellow to greenish yellow thallus (vs. dark brownish), wider lobes $0.5-1 \mathrm{~mm}$ wide (vs. $0.1-0.3 \mathrm{~mm}$ wide), thick cortex 20-46 $\mu \mathrm{m}$ (vs. 12-20 $\mu \mathrm{m}$ ), thick and well-defined algal layer 40-57 $\mu \mathrm{m}$ (vs. diffuse, 25-40 $\mu \mathrm{m}$ ), and frequent occurrence of apothecia (vs. none; Yin et al., 2019). Another representative of the genus, $P$. opaca, reported from Spain, shows morphological similarity to $P$. kashmirensis due to its yellowish-brown thallus and contiguous lobes (Yin et al., 2019). Thalline lobes of $P$. kashmirensis are somewhat shorter and narrower, especially towards tips $(0.5-1 \mathrm{~mm}$ wide vs. elongated, 3-4.5 $\mathrm{mm}$ wide), higher 

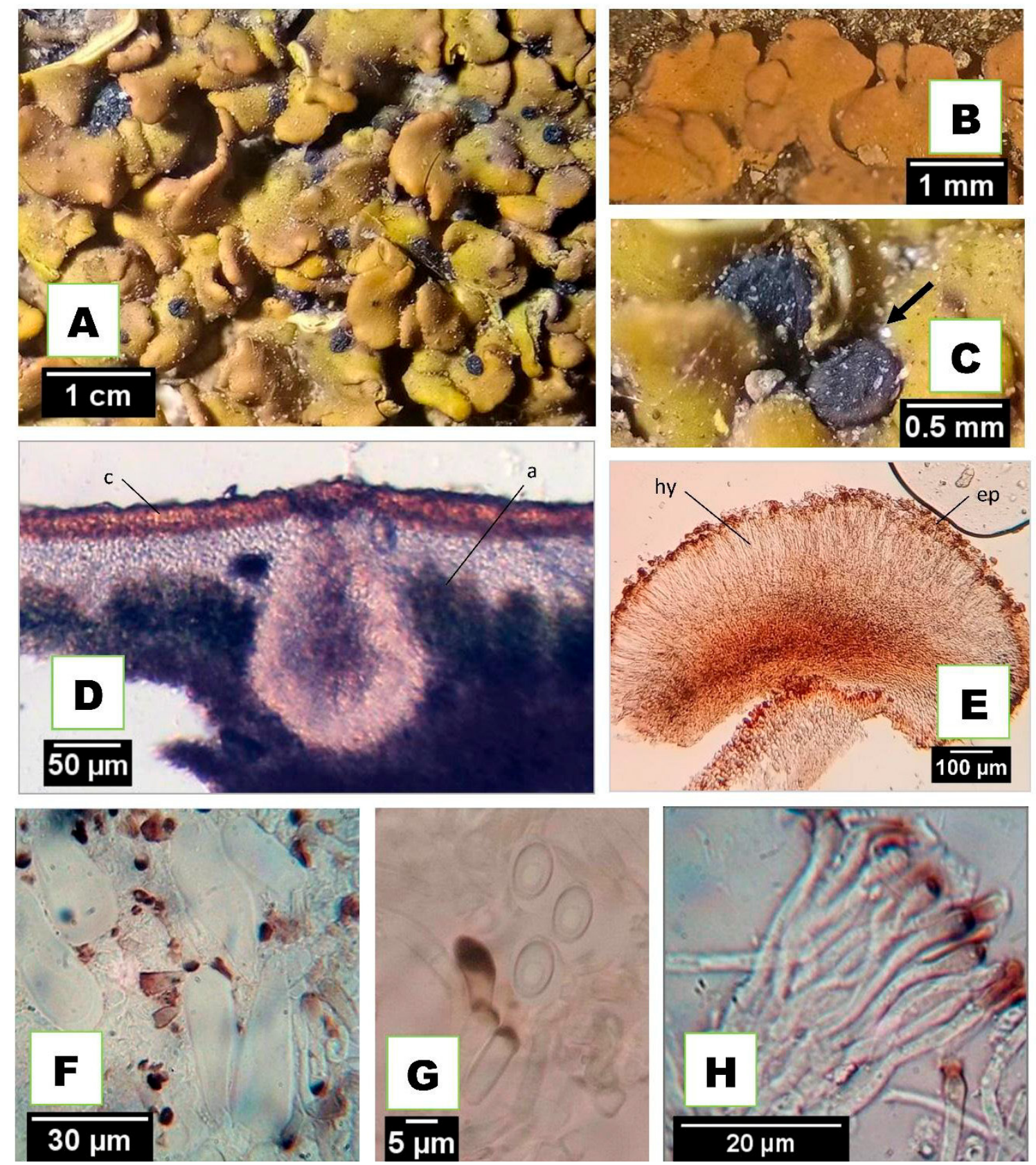

Fig. 2. (A-H) Placolecis kashmirensis (Holotype). A - showing squamulose thallus; B -lobate margins; C - apothecia; D - cross section of thallus and pycnidium (a: algal layer; c: cortex); E-cross section of apothecium (ep: epihymenium; hy: hymenium); F - asci; G -ascospores; H - paraphyses. 
hymenium (100-130 $\mu \mathrm{m}$, vs. $50 \mu \mathrm{m})$, and plane disc of apothecia (vs. convex). The ascospore size of both species also vary, smaller in $P$. kashmi-

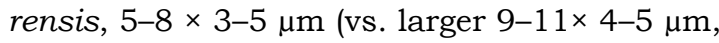
in P. opaca; Kondratyuk et al., 2017). Placolecis kashmirensis is also similar to $P$. loekoesiana but differs in having slightly shorter thalline lobes (0.5-1 $\mathrm{mm}$ wide vs. $0.5-1.5 \mathrm{~mm}$ wide), in having reddish-brown to white medulla, in having hyaline and much higher hymenium (100-130 $\mu \mathrm{m}$, vs. dark brown, $75 \mu \mathrm{m}$ ) and in having smaller ascospores 5-8 × 3-5 $\mu \mathrm{m}$ (vs. larger 10-14 × 5-6 $\mu \mathrm{m}$; Kondratyuk et al., 2017). From Placolecis kunmingensis, P. kashmirensis differs in having wider lobes $0.5-1 \mathrm{~mm}$ (vs. $0.2-0.3 \mathrm{~mm}$ wide), yellowish brown upper surface (vs. dark brownish), taller epihymenium (25-40 $\mu \mathrm{m})$ and hymenium (100-130 $\mu \mathrm{m})$, (vs. smaller 7-15 $\mu \mathrm{m}$ and $50-75 \mu \mathrm{m}$ ) respectively, septate paraphyses (vs. simple), and slightly smaller ascospores 5-8 $\times 3-5 \mu \mathrm{m}$ (vs. 5-10 × 4-6 $\mu \mathrm{m}$; Yin et al., 2019).

\section{Key to the worldwide Placolecis species}

1. Thallus dark brown .............................. 2

1. Thallus yellow to yellowish brown .......... 4

2 (1) Algal layer diffuse, 25-40 $\mu \mathrm{m}$ P. sublaevis

2 (1) Algal layer uniform, 50-70 $\mu \mathrm{m} . . . \ldots \ldots . . .3$

3 (2) Apothecia frequent, plane, medulla reddish orange to white, hymenium 50$75 \mu \mathrm{m}$ high, ascospores simple, smaller, 5$10 \times 4-6 \mu \mathrm{m}$.................... kunmingensis

3 (2) Apothecia rare, plane to convex, medulla ochre to reddish orange, hymenium up to $50 \mu \mathrm{m}$ high, ascospores simple to septate, larger, 9-11 × 4-5 $\mu \mathrm{m}$

P. opaca

4 (2) Apothecia rare, medulla yellow, hymenium dark brown, up to $75 \mu \mathrm{m}$ high, ascospores simple, larger, 10-14 × 5-6 $\mu \mathrm{m}$

P. loekoesiana

4 (2) Apothecia frequent, medulla reddish brown to white, hymenium hyaline, 100-130 $\mu \mathrm{m}$ high, ascospores simple, smaller, 5-8 $\times$ 3-5 $\mu \mathrm{m}$ P. kashmirensis

\section{ACKNOWLEDGEMENTS}

We are sincerely thankful to Prof. Dr. Sergey Yakoyych Kondratyuk, Kholodny Institute of Botany, National Academy of Sciences of Ukraine, for pre-submission review of the manuscript. We also thank the two anonymous reviewers whose suggestions helped to improve and clarify this manuscript.

\section{REFERENCES}

Aptroot, A. \& Moon, K. H. 2014. 114 new reports of microlichens from Korea, including the description of five new species, show that the microlichen flora is predominantly Eurasian. Herzogia 27(2): 347-365.

Gardes, M. \& Bruns, T. D. 1993. ITS primers with enhanced specificity for basidiomycetes-application to the identification of mycorrhizae and rusts. Molecular Ecology 2(2): 113-118.

Hall, T. A. 2005. Bioedit Version 7.0.4. Department of Microbiology. North Carolina State University.

Katoh K, Standley, D. M. 2013. MAFFT multiple sequence alignment software version 7 , improvement in performance and usability. Molecular Biology and Evolution 30: 772-780.

Kondratyuk, S.Y., Lőkös, L., Halda, J. P., Roux, C., Upreti, D. K., Schumm, F ., ... , Hur, J. S. 2017. New and noteworthy lichen-forming and lichenicolous fungi 6. Acta Botanica Hungarica 59(1-2): 137-260.

Makryi, T. V. 2003. Placolecis opaca (Catillariaceae), a new to Russia lichen genus and species from Dauria (Chita region). Botanicheskiy Zhurnal 88: 123-127. (In Russian).

Orange, A., James, P. W. \& White, F. J. 2001. Microchemical methods for the identification of lichens. London (UK): British Lichen Society, Natural History Museum.

Sambrook, J. \& Russell, D. W. 2001. Detection of DNA in agarose gels. Molecular Cloning, A Laboratory Manual, (3rd Ed.) Cold Spring Harbor Laboratory Press. New York, pp. 5-14.

Sinha, G. P., Gupta, P., Kar, R. \& Joseph, S. 2015. A checklist of Lichens of Rajasthan, India. Current Research in Environmental \& Applied Mycology 5(4): 367-375.

Tamura, K., Stecher, G., Peterson, D., Filipski, A. \& Kumar, S. 2013. MEGA6: molecular evolutionary genetics analysis version 6.0. Molecular biology and evolution 30(12): 2725-2729.

White, T. J., Bruns, T. D., Lee, S. B. \& Taylor, J. W. 1990. Amplification and Direct Sequencing of Fungal Ribosomal RNA Genes for Phylogenetics. In: Innis, M. A., Gelfand, D. H., Sninsky, J. J. \& White, T. J. (eds). PCR Protocols: A Guide to Methods and Applications, Academic Press, New York, pp. 315-322.

Yin, A. C., Wang, X. Y., Liu, D., Zhang, Y. Y., Yang, M. X., Li, L. J. \& Wang, L. S. 2019. Two New Species of Placolecis (Lichenized Ascomycota) from China. Mycobiology 47(4): 401-407. 
Appendix 1. Taxa used in the phylogenetic analyses. The sequence generated in the present study is marked with *.

\begin{tabular}{|c|c|c|c|}
\hline Taxa & Accession No. & Voucher No. & Country \\
\hline Austrolecia sp. & JX036083 & s178 & Antarctica \\
\hline Austrolecia sp. & JX036047 & s116 & Antarctica \\
\hline Austrolecia sp. & JX036089 & s184 & Antarctica \\
\hline Austrolecia sp. & JX036104 & s200 & Antarctica \\
\hline Austrolecia sp. & JX036103 & s199 & Antarctica \\
\hline Catillaria corymbosa & DQ534457 & Hur ANT050798 & Antarctica \\
\hline Catillaria scotinodes & MG925964 & O:L 161161 & Norway \\
\hline Lecidea atrobrunnea & KX120206 & UR00200 & Argentina \\
\hline Lecidea tessellata & KX120213 & UR00138 & Argentina \\
\hline *Placolecis kashmirensis & MW586931 & MAK-11 & Pakistan \\
\hline Placolecis kunmingensis & MK995884 & 18-58078-(KUN-holotype) & China \\
\hline Placolecis kunmingensis & MK995879 & 56795-(KUN) & China \\
\hline Placolecis loekoesiana & MN052962 & 041238 (KoLRI) & South Korea \\
\hline Placolecis opaca & MK995882 & Inv.Nr.8763 & Spain \\
\hline Placolecis opaca & MK995885 & Inv.Nr.8764 & Spain \\
\hline Placolecis sublaevis & MK995874 & $19-62675(\mathrm{KUN})$ & China \\
\hline Solenopsora cesatii & KF689850 & cesatii_19_FR (Herbarium J. Malicek,Sedlcany) & France \\
\hline Solenopsora grisea & KF689875 & grisea_9_AL (Herbarium BP) & Albania \\
\hline Solenopsora liparina & KF689879 & liparina_3_CZ (Herbarium SAV) & Czech Republic \\
\hline Solenopsora marina & KF689883 & marina_4_FR (Herbarium SAV) & France \\
\hline Solenopsora olivacea & KF689889 & olivacea_3_ME (Herbarium O) & Montenegro \\
\hline Solenopsora vulturiensis & KF689897 & vulturiensis_4_FR (Herbarium SAV) & France \\
\hline Teloschistes exilis & JQ301684 & D. Hillis 07-726 (DUKE) & USA \\
\hline Teloschistes flavicans & JQ301685 & F. Lutzoni, J. Miadlikowska, R. Lucking 03.22.03-13A (DUKE) & Costa Rica \\
\hline
\end{tabular}

